\title{
ACE I/D Polymorphism in Hypertensive Patients of Kashmiri Population
}

\author{
A. Syed Sameer, b, Nidda Syeed ${ }^{\mathrm{a}}$, Shahid A. Tak ${ }^{\mathrm{c}}$, Samina Bashir ${ }^{\mathrm{d}}$, \\ Saniya Nissar ${ }^{\mathrm{a}, \mathrm{d}}$, Mushtaq A. Siddiqi ${ }^{\mathrm{a}, \mathrm{e}}$
}

\begin{abstract}
Background: The angiotensin-converting enzyme (ACE) gene in humans has an insertion-deletion (I/D) polymorphic state in intron 16 on chromosome $17 q 23$. This polymorphism has been widely investigated in different diseases. In this study we aimed to investigate the ACE I/D genotype frequency in hypertensive cases in Kashmiri population.
\end{abstract}

Methods: We designed a case control study, where 52 hypertensive cases were studied for ACE I/D polymorphism against 150 age/ sex matched controls taken from general population. The polymorphisms of ACE gene were investigated using polymerase chain reaction for detection of ACE I/D genotype. Fisher's Chi square test was used for calculation of $\mathrm{P}$ value and $\mathrm{OR}$.

Results: We found the frequency of ACE DD genotype to be $46.15 \%$ (24/52), II $23.07 \%(12 / 52)$ and DI $30.77 \%(16 / 52)$ in 52 hypertensive cases.

Conclusions: The ACE I/D genotype is positively associated with hypertension in our population.

Keywords: Hypertension; ACE; Polymorphism; RFLP; Kashmir

\footnotetext{
Manuscript accepted for publication October 4, 2010

${ }^{a}$ Departments of Immunology and Molecular Medicine, Sher-I-Kashmir Institute of Medical Sciences, Soura, Srinagar, Kashmir, 190011, India

${ }^{b}$ Departments of Clinical Biochemistry, Sher-I-Kashmir Institute of Medical Sciences, Soura, Srinagar, Kashmir, India

${ }^{c}$ Departments of Cardiology, Sher-I-Kashmir Institute of Medical Sciences, Soura, Srinagar, Kashmir, India

${ }^{\mathrm{d}}$ Department of Clinical Biochemistry, Kashmri University, Hazratbal, Srinagar, Kashmir, India

eCorresponding author: vc.tmuk@gmail.com
}

doi: $10.4021 /$ cr101e

\section{Introduction}

Hypertension (HT, HTN or HPN) is a chronic medical condition in which the blood pressure is elevated [1]. Hypertension is categorized into essential (primary) representing 90-95\% of cases and secondary which occurs as a result of other conditions, such as kidney disease or tumors (adrenal adenoma or pheochromocytoma) [2]. The prevalence of hypertension in India varies from as less as 30\% to as much as 61\% [3-8]. The Sentinel Surveillance Project (WHO) [9] documented $28 \%$ overall prevalence of hypertension $($ criteria: $=\mathrm{JNC}$ VI) from 10 regions of the country in the age group of $20-69$. The scenario in Kashmir is not different from the reported literature from other parts of the India, because of the two decade long turmoil raging in all corners of the valley. Based on the medical registry of Sher-i-Kashmir Institute of Medical Sciences (SKIMS), hypertension in Kashmir is found in almost $60 \%$ of the population.

Angiotensin-converting enzyme (ACE), a key zinc metalloenzyme of the rennin-angiotensin system is widely distributed in body in the kidney [10]. The ACE catalyzes the conversion of angiotensin I to the biologically active peptide, angiotensin II, which is involved in the control of fluidelectrolyte balance and systemic blood pressure [11].

The ACE gene is located on long arm of chromosome 17 (17q23.3). The gene is 21 kilo bases (kb) long and comprises 26 exons and 25 introns. More than 160 ACE gene polymorphisms have been reported so far and most of which are single nucleotide polymorphisms (SNPs). Only 34 of those polymorphisms are located in coding region of this gene [12]. Rigat et al (1990) was the first to report the insertion/ deletion (I/D) polymorphism of ACE [13]. This polymorphism is characterized by the presence (insertion) or absence (deletion) of a 287 bp AluYa5 element inside intron 16 producing three genotypes (II homozygote, ID heterozygote and DD homozygote). Although I/D polymorphism is located in a non-coding region (namely intron) of the ACE gene, several investigators have found that the $\mathrm{D}$ allele is related to increased activity of ACE in serum. The highest serum ACE activity was seen in the DD genotype while the lowest was seen in the II genotype [14]. The number of studies carried 
out around the world suggested the genetic predisposition of the ACE I/D polymorphism with several diseases including coronary heart diseases, stroke, hypertension and diabetes mellitus [15-18]. However, conflicting results have been reported regarding the association between ACE polymorphism and disease $[19,20]$. Moreover, various reports were published suggesting inter-ethnic variations in the frequency of allelic forms of the ACE genes [21, 22].

Angiotensin II is an aldosterone-stimulating peptide with a direct, potent vasopressive effect on the peripheral vasculature, and plays a pivotal role in electrolyte and circulatory homeostasis. It is converted from its precursor, angiotensin I, by the catalytic action of the dipeptidylcarboxypeptidase-ACE [23]. As the ACE I/D polymorphism is partially associated with the plasma ACE level [24], the ACE DD genotype increases the plasma ACE concentration and the risk for numerous cardiovascular-renal diseased states, such as myocardial infarction, cardiomyopathy, IgA nephropathy, and diabetic nephropathy. The findings from case-control studies have not been consistently positive [25-29].

Therefore, we carried out a case-control study in our population to determine if this ACE I/D polymorphism is associated with an altered risk of hypertension in our population.

\section{Materials and Methods}

\section{Study population}

This study included 52 hypertensive and cardiac patients. All patients were recruited from Department of Cardiology of this Institute from March 2009 to February 2010. Hypertension was defined by the use of one or more antihypertensive medications and/or a blood pressure not less than $140 \mathrm{~mm}$ $\mathrm{Hg}$ systolic or $90 \mathrm{~mm} \mathrm{Hg}$ diastolic. Blood samples of 150 age and sex matched cases with no signs of any cardiac disease were collected to serve as external controls.

Data on all CRC patients were obtained from personal interviews with patients and/or guardians and medical records. The clinical characteristics of the patients at the time of diagnosis, including age, gender, dwelling, stress level, office blood pressure, urinary protein excretion $(\mathrm{g} / \mathrm{d})$, serum creatinine level $(\mathrm{sCr}, \mathrm{mg} / \mathrm{dL})$, and 24-hour creatinine clearance $(\mathrm{CCr}, \mathrm{mL} / \mathrm{min})$ were retrospectively investigated. Echocardiographic analysis of all hypertensive cases was carried out to know the severity of aortic valve calcification. All patients and/or guardians were informed about the study and their will to participate in this study was taken on predesigned questionnaire (available on request). The collection and use of blood samples (from patients and controls) for this study were previously approved by the appropriate Institutional Ethics Committee.

\section{DNA extraction and polymerase chain reaction}

DNA extraction was performed using ammonium acetate precipitation method. Polymorphism in intron 16 of the ACE gene was assessed by polymerase chain reaction (PCR) under conditions that have been previously described [10].

The specific segment of ACE gene was amplified by using previously reported primers (Table 1) [10], which amplified $190 \mathrm{bp}$ amplicon in case of homozygous DD genotype, $490 \mathrm{bp}$ in case of homozygous II genotype and both in case of heterozygous DI genotype (Fig. 1). All samples that were identified initially as a DD genotype were reanalyzed using an insertion-specific primer pair, as reported by Lindpaintner et al [30], except that the annealing temperature was $67^{\circ} \mathrm{C}$. A 335 bp band was obtained only in the presence of the I allele and no bands were detected for samples with DD genotype. PCR was carried out in a final volume of $25 \mu \mathrm{L}$ containing 50 ng genomic DNA template, 1 X PCR buffer (Fermentas) with $2 \mathrm{mM} \mathrm{MgCl}, 0.4 \mu \mathrm{M}$ of each primer (Genescript), 50 $\mu \mathrm{M}$ dNTPs (Fermentas) and 0.5 U DNA polymerase (Fermentas). For PCR amplification, the stan $\neg$ dard program was used as follows: one initial denaturation step at $94^{\circ} \mathrm{C}$ for 7 min, followed by 30 denaturation cycles of $30 \mathrm{~s}$ at $94^{\circ} \mathrm{C}, 45 \mathrm{~s}$ of annealing at $58^{\circ} \mathrm{C}$, and $45 \mathrm{~s}$ of extension at $72^{\circ} \mathrm{C}$, followed by a final elongation cycle at $72^{\circ} \mathrm{C}$ for $7 \mathrm{~min}$.

DNA amplicons were electrophoresed through a $2-3 \%$ agarose gel for resolution. The genotypes of more than $20 \%$ of the samples were double blindly reassessed to confirm the

Table 1. Primers for ACE gene Polymorphism

\begin{tabular}{llll}
\hline Target Codon & Sequence & Amplicon (bp) & $\mathbf{T}_{\mathbf{m}}\left({ }^{\mathbf{0}} \mathbf{C}\right)$ \\
\hline \multirow{2}{*}{ ACE } & F 5'-CTGGAGACCACTCCCATCCTTTCT -3' & 490bp for II & 58 \\
& R 5'-GATGTGGCCATCACATTCGTCAGAT -3' & 190bp for DD & \\
ACE I & F5-TGGGACCACAGCGCCCGCCACTAC -3' & $335 \mathrm{bp}$ & 67 \\
& R5- TCGCCAGCCCTCCCATGCCCATAA-3' & & \\
\hline
\end{tabular}




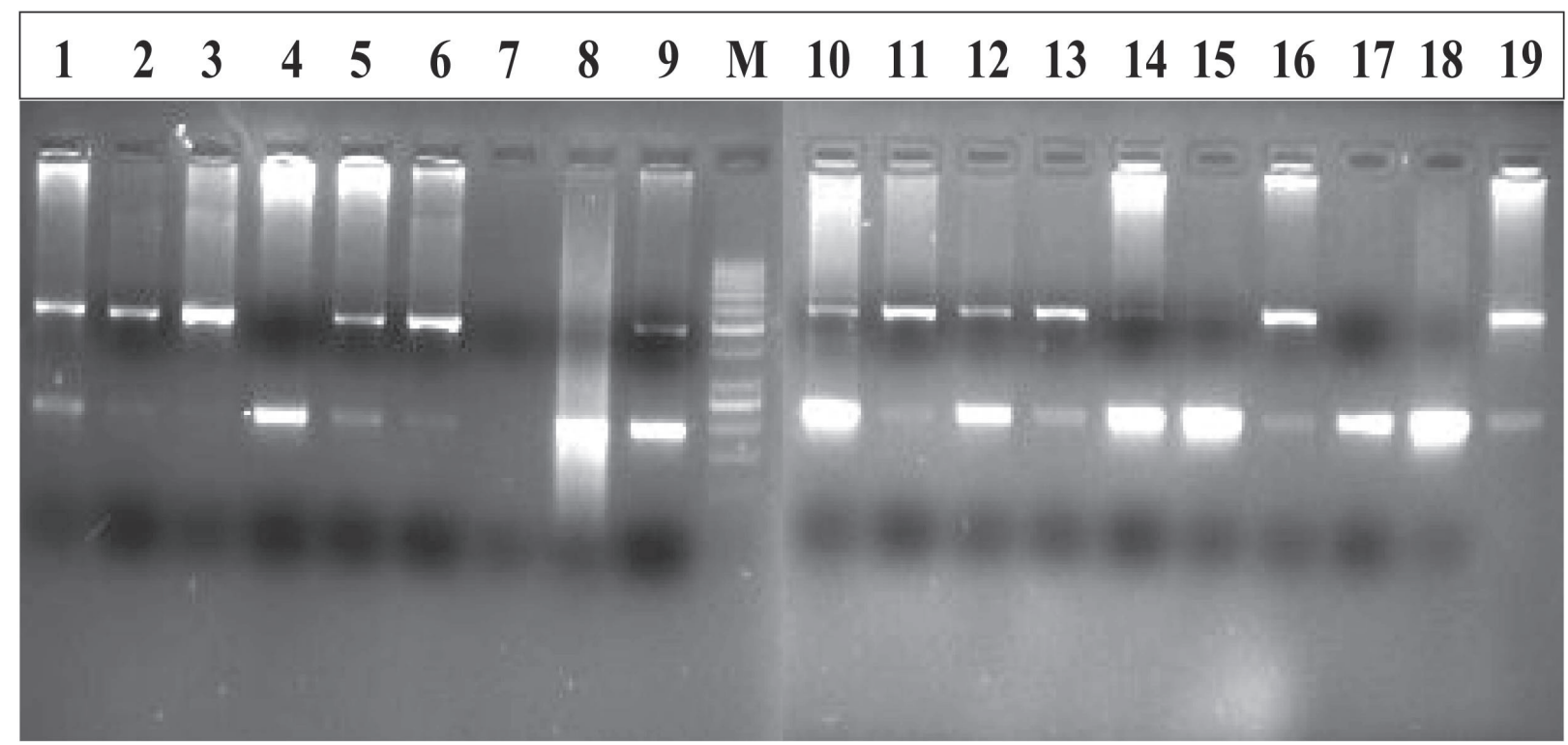

Figure 1. Representative gel picture of ACE DI polymorphism by differential amplification of intron 16 of the ACE gene. Lane M: 50bp ladder; Lanes 1, 2, 5, 6, 9, 10, 11, 12, 13, 14, 16 and 19 show DI form; Lanes 4, 8, 15, 17, 18 and 12 show DD form; Lane 3 shows II form.

results by two independent researchers. A positive control for each polymorphism was used for $50 \%$ of samples.

\section{Statistical analysis}

Observed frequencies of genotypes in hypertensive patients

Table 2. Frequency Distribution Analysis of Selected Demographic and Risk Factors in Hypertensive Cases and Controls

\begin{tabular}{llll}
\hline Variable & $\begin{array}{l}\text { Cases } \\
(\mathbf{n}=\mathbf{5 2})\end{array}$ & $\begin{array}{l}\text { Controls } \\
(\mathbf{n}=\mathbf{1 5 0})\end{array}$ & P Value* \\
\hline $\begin{array}{l}\text { Age group } \\
\quad<50\end{array}$ & 25 & 77 & 0.74 \\
$\geq 50$ & 27 & 73 & \\
Gender & & & \\
$\quad$ Female & 14 & 50 & 0.48 \\
$\quad$ Male & 38 & 100 & \\
Dwelling & & & \\
$\quad$ Rural & 30 & 78 & 0.52 \\
$\quad$ Urban & 22 & 72 & \\
Smoking status & & & \\
$\quad$ Never & 30 & 92 & 0.74 \\
$\quad$ Ever & 22 & 58 & \\
\hline
\end{tabular}

*Two tailed fisher test were compared to con $\neg$ trols using chi-square or Fisher exact tests when expected frequencies were small. The chi-square test was used to verify whether genotype distributions were in Hardy-Weinberg equilibrium. Statistical significance was set at $\mathrm{P}<0.05$. Statistical analyses were performed with PASW version 18 Software.

\section{Results}

A total of 52 hypertensive patients and 150 control subjects were included in this study. Subjects with completely normal echo-cardiographic study were taken as controls. The patients comprised 38 males and 14 females $(\mathrm{M} / \mathrm{F}$ ratio $=$ 2.7) and the control subjects consisted of 100 males and 50 females $(\mathrm{M} / \mathrm{F}$ ratio $=2)$. Mean age in patients and control

Table 3. Genotype Frequencies of ACE Intron 16 Gene Polymorphism in Cases and Controls

\begin{tabular}{llll}
\hline $\begin{array}{l}\text { ACEs } \\
\text { Genotype }\end{array}$ & $\begin{array}{l}\text { Cases } \\
(\mathbf{n}=\mathbf{5 2})\end{array}$ & $\begin{array}{l}\text { Controls } \\
(\mathbf{n}=\mathbf{1 5 0})\end{array}$ & P Value \\
\hline DD & $24(46.15 \%)$ & $80(53.33 \%)$ & 0.245367 \\
DI & $16(30.77 \%)$ & $49(32.77 \%)$ & \\
II & $12(23.07 \%)$ & $21(14.00 \%)$ & \\
\hline
\end{tabular}


Table 4. Genotype Frequencies of ACE Intron 16 Gene Polymorphism in Cases and Controls

\begin{tabular}{llll}
\hline ACEs Genotype & $\begin{array}{l}\text { Cases } \\
(\mathbf{n}=\mathbf{5 2})\end{array}$ & $\begin{array}{l}\text { Controls } \\
(\mathbf{n}=\mathbf{1 5 0})\end{array}$ & OR (95\% CI ) \\
\hline DD & $24(46.15 \%)$ & $80(53.33 \%)$ & $\operatorname{Ref}(1)$ \\
DI & $16(30.77 \%)$ & $49(32.77 \%)$ & $1.08(0.52-2.24)$ \\
II & $12(23.07 \%)$ & $21(14.00 \%)$ & $1.90(0.81-4.42)$ \\
DI+II & $28(53.84 \%)$ & $69(46.77 \%)$ & $1.35(0.71-2.54)$ \\
\hline
\end{tabular}

groups was 52 years. No significant gender- or age-related differences were ob $\urcorner$ served between the groups $(P>0.05)$. Furthermore, among hypertensive patients 30 were rural and 22 urban; 22 were smokers and 30 non smokers (Table 2).

In this study, among 52 hypertensive cases we found the frequency of ACE DD genotype to be $46.15 \%$ (24/52), II $23.07 \%(12 / 52)$ and DI $30.77 \%$ (16/52), while as in general control (150) population the DD frequency is $53.33 \%$ (80/150), II $14.00 \%$ (21/150) and DI $32.77 \%$ (49/150). The association of ACE I/D polymorphism with the hypertensive cases was not found to be significant $(\mathrm{p}>0.05)$ (Table 3$)$.

Furthermore, the hazard ratio of ACE DI genotype in hypertensive cases was found to be 1.08 times and of ACE II genotype 1.90 times that of general control population, indicating thereby that ACE I allele is associated with the increased risk of hypertension (Table 4).

Echo-cardiographic analysis of hypertensive cases vealed that nine cases had mild, 27 had moderate and 16 had severe calcification (Table 5 and 6 ). ACE I/D analysis showed that among 27 moderate AVC cases, eight had DI and two II genotype; and among 16 severe AVC cases, five

Table 5. Relationship of ACE I/D Polymorphism and AVC Status

\begin{tabular}{llll}
\hline ACE Genotype & $\begin{array}{l}\text { Mild } \\
(\mathbf{n}=\mathbf{9})\end{array}$ & $\begin{array}{l}\text { MVC Status } \\
(\mathbf{n}=\mathbf{2 7})\end{array}$ & $\begin{array}{l}\text { Severe } \\
(\mathbf{n}=\mathbf{1 6})\end{array}$ \\
\hline DD $(\mathrm{n}=24)$ & 4 & 17 & 3 \\
DI $(\mathrm{n}=16)$ & 3 & 8 & 5 \\
II $(\mathrm{n}=12)$ & 2 & 2 & 8 \\
DI + II $(\mathrm{n}=28)$ & 5 & 10 & 13 \\
\hline
\end{tabular}

had DI and eight II genotype. Also, 53.5\% (23/43) higher AVC cases had ACE I allele in either homozygous or heterozygous form.

\section{Discussion}

Kashmir also called 'Pir-e-Waer' is one of the picturesque place on earth located in the northern part of India. In between, the Himalayas is home of one of the oldest ethnic population that has been proven beyond doubt to be exposed to a special set of environmental and dietary risks which include consumption of sun-dried and smoked fish and meat, dried and pickled vegetables, red chilly, Hakh (a leafy vegetable of Brassica family), hot noon chai (salted tea), and Hukka (water pipe) smoke [31, 32].

The etiology of primary hypertension is unknown however its diverse hemodynamic and pathophysiologic derangements are unlikely to result from a single cause [33]. Heredity is one of the main predisposing factors, but the exact mechanism is unclear [34]. Various environmental fac-

Table 6. Correlation of ACE I/D Polymorphism and AVC Status

\begin{tabular}{llll}
\hline & & \multicolumn{2}{c}{ AVC Status } \\
ACE Genotype & $\begin{array}{l}\text { Mild } \\
(\mathbf{n}=\mathbf{9})\end{array}$ & $\begin{array}{l}\text { Moderate/ } \\
\text { Severe } \\
(\mathbf{n}=\mathbf{4 3})\end{array}$ & $\begin{array}{l}\text { OR } \\
\mathbf{( 9 5 \%} \text { CI })\end{array}$ \\
\hline DD $(\mathrm{n}=24)$ & 4 & 20 & Ref $=1$ \\
DI $(\mathrm{n}=16)$ & 3 & 13 & $1.15(0.22-6.02)$ \\
II $(\mathrm{n}=12)$ & 2 & 10 & $1.0(0.16-6.42)$ \\
DI + II $(\mathrm{n}=28)$ & 5 & 23 & $1.08(0.26-4.6)$ \\
\hline
\end{tabular}


tors (for exemple, high salt intake, obesity, stress) seem to act only in genetically susceptible persons [35]. The reninangiotensin system (RAS) has been identified by many studies to be the most important of the endocrine systems that affect the control of blood pressure [36-38].

In our study on hypertensive patients of Kashmir, we found that among 52 hypertensive cases the frequency of ACE DD genotype to be $46.15 \%$ (24/52), II $23.07 \%(12 / 52)$ and DI $30.77 \%(16 / 52)$ however no statistical significance was observed between the ACE gene I/D polymorphism and hypertension. This was in tune with other studies [38-40].

However, on the other hand, a significant association of the ACE D allele with hypertension in African Americans, Chinese and Japanese population has already been established [41-44]. In one of the seminal study in the same region of the sub-continent in Pakistani population, it was shown that I allele is associated with hypertension [45]. The association of I allele with hypertension in Pakistani population may be attributed to the presence of high levels of inbreeding, thereby resulting in higher heterozygosity. The heterogeneity in association of ACE I/D polymorphism with essential hypertension may be either due to varied ethnicity [21] or the various other genetic and environmental factors implicated in the regulation of blood pressure [46]. Any variation in even a single etiological factor could lead to difference in blood pressure and thereby hypertension. Another study carried out in Bangladeshi population found a significant association of ACE I/D polymorphism with hypertension [47]. In other two studies on ACE I/D polymorphism in hypertensive cases, carried out on two geographical opposite populations (Punjabi and Southern) in India, a positive association was observed [48, 49].

Furthermore, Echo-cardiographic analysis of hypertensive cases in relation to ACE genotype revealed among 27 moderate AVC cases, eight had DI and only two had II genotype; and among 16 severe AVC cases, five had DI and eight had II genotype. Also, 53.5\% (23/43) higher AVC cases had ACE I allele in either homozygous or heterozygous form. The ACE I/D polymorphism has been already identified as one of the risk factors of AVC [50]. The insertion/deletion polymorphism in the ACE gene is correlated with the circulating ACE levels. Individuals with II genotype have the lowest circulating ACE levels as compared to DD genotype, which are known to have high ACE levels [51].

In conclusion, the present study carried out for the first time in our population clearly indicates the strong association of ACE I/D polymorphism with hypertension. However, the data need validation in a large cohort study.

\section{References}

1. Anthea M, Hopkins J, McLaughlin CW, Johnson S, Warner MQ, LaHart D, et al. Human Biology and Health.
Englewood Cliffs, New Jersey, USA: Prentice Hall. 1993.

2. Oparil S, Zaman MA, Calhoun DA. Pathogenesis of hypertension. Ann Intern Med 2003;139(9):761-776.

3. Kutty VR, Balakrishnan KG, Jayasree AK, Thomas J. Prevalence of coronary heart disease in the rural population of Thiruvananthapuram district, Kerala, India. Int J Cardiol 1993;39(1):59-70.

4. Kutty VR, Soman CR, Joseph A, Kumar KV, Pisharody R. Random capillary blood sugar and coronary risk factors in a south Kerala population. J Cardiovasc Risk 2002;9(6):361-367.

5. Hazarika NC, Biswas D, Narain K, Kalita HC, Mahanta J. Hypertension and its risk factors in tea garden workers of Assam. Natl Med J India 2002;15(2):63-68.

6. Gupta R, Sarna M, Thanvi J, Rastogi P, Kaul V, Gupta VP. High prevalence of multiple coronary risk factors in Punjabi Bhatia community: Jaipur Heart Watch-3. Indian Heart J 2004;56(6):646-652.

7. Mohan V, Shanthirani S, Deepa R, Premalatha G, Sastry NG, Saroja R. Intra-urban differences in the prevalence of the metabolic syndrome in southern India -- the Chennai Urban Population Study (CUPS No. 4). Diabet Med 2001;18(4):280-287.

8. Swami HM, Bhatia V, Gupta M, Bhatia SP, Sood A. Population based study of hypertension among the elderly in northern India. Public Health 2002;116(1):4549.

9. International Statistical Classification of Diseases and Related Health Problems - 10th revision (1994), World Health Organization, Geneva.

10. Salem AH, Batzer MA. High frequency of the D allele of the angiotensin-converting enzyme gene in Arabic populations. BMC Res Notes 2009;2(99.

11. Wang JG, Staessen JA. Genetic polymorphisms in the renin-angiotensin system: relevance for susceptibility to cardiovascular disease. Eur J Pharmacol 2000;410(23):289-302.

12. Sayed-Tabatabaei FA, Oostra BA, Isaacs A, van Duijn CM, Witteman JC. ACE polymorphisms. Circ Res 2006;98(9):1123-1133.

13. Rigat B, Hubert C, Alhenc-Gelas F, Cambien F, Corvol $\mathrm{P}$, Soubrier F. An insertion/deletion polymorphism in the angiotensin I-converting enzyme gene accounting for half the variance of serum enzyme levels. J Clin Invest 1990;86(4):1343-1346.

14. Sakuma T, Hirata RD, Hirata MH. Five polymorphisms in gene candidates for cardiovascular disease in AfroBrazilian individuals. J Clin Lab Anal 2004;18(6):309316.

15. Obineche EN, Frossard PM, Bokhari AM. An association study of five genetic loci and left ventricular hypertrophy amongst Gulf Arabs. Hypertens Res 2001;24(6):635-639. 
16. Zee RY, Ridker PM, Stampfer MJ, Hennekens $\mathrm{CH}$, Lindpaintner K. Prospective evaluation of the angiotensin-converting enzyme insertion/deletion polymorphism and the risk of stroke. Circulation 1999;99(3):340-343.

17. Gesang L, Liu G, Cen W, Qiu C, Zhuoma C, Zhuang L, Ren D, et al. Angiotensin-converting enzyme gene polymorphism and its association with essential hypertension in a Tibetan population. Hypertens Res 2002;25(3):481485.

18. Kennon B, Petrie JR, Small M, Connell JM. Angiotensin-converting enzyme gene and diabetes mellitus. Diabet Med 1999;16(6):448-458.

19. Moleda P, Majkowska L, Safranow K, Adler G, Goracy I. [Relationship between I/D polymorphism of angiotensin I converting enzyme gene and microvascular complications in type 2 diabetic patients]. Przegl Lek 2007;64(3):134-139.

20. Taal MW. Angiotensin-converting enzyme gene polymorphisms in renal disease: clinically relevant? Curr Opin Nephrol Hypertens 2000;9(6):651-657.

21. Barley J, Blackwood A, Carter ND, Crews DE, Cruickshank JK, Jeffery S, Ogunlesi AO, et al. Angiotensin converting enzyme insertion/deletion polymorphism: association with ethnic origin. J Hypertens 1994;12(8):955-957.

22. Saha N, Talmud PJ, Tay JS, Humphries SE, Basair J. Lack of association of angiotensin-converting enzyme (ACE). Gene insertion/deletion polymorphism with CAD in two Asian populations. Clin Genet 1996;50(3):121-125.

23. Koh WP, Yuan JM, Sun CL, van den Berg D, Seow A, Lee $\mathrm{HP}, \mathrm{Yu} \mathrm{MC}$. Angiotensin I-converting enzyme (ACE) gene polymorphism and breast cancer risk among Chinese women in Singapore. Cancer Res 2003;63(3):573578.

24. Villard E, Tiret L, Visvikis S, Rakotovao R, Cambien F, Soubrier F. Identification of new polymorphisms of the angiotensin I-converting enzyme (ACE) gene, and study of their relationship to plasma ACE levels by twoQTL segregation-linkage analysis. Am J Hum Genet 1996;58(6):1268-1278.

25. Cambien F, Poirier O, Lecerf L, Evans A, Cambou JP, Arveiler D, Luc G, et al. Deletion polymorphism in the gene for angiotensin-converting enzyme is a potent risk factor for myocardial infarction. Nature 1992;359(6396):641-644.

26. Marian AJ, Yu QT, Workman R, Greve G, Roberts R. Angiotensin-converting enzyme polymorphism in hypertrophic cardiomyopathy and sudden cardiac death. Lancet 1993;342(8879):1085-1086.

27. Harden PN, Geddes C, Rowe PA, McIlroy JH, BoultonJones M, Rodger RS, Junor BJ, et al. Polymorphisms in angiotensin-converting-enzyme gene and progression of IgA nephropathy. Lancet 1995;345(8964):1540-1542.

28. Marre M, Bernadet P, Gallois Y, Savagner F, Guyene
TT, Hallab M, Cambien F, et al. Relationships between angiotensin I converting enzyme gene polymorphism, plasma levels, and diabetic retinal and renal complications. Diabetes 1994;43(3):384-388.

29. Higaki J, Baba S, Katsuya T, Sato N, Ishikawa K, Mannami T, Ogata J, et al. Deletion allele of angiotensinconverting enzyme gene increases risk of essential hypertension in Japanese men : the Suita Study. Circulation 2000;101(17):2060-2065.

30. Lindpaintner K, Pfeffer MA, Kreutz R, Stampfer MJ, Grodstein F, LaMotte F, Buring J, et al. A prospective evaluation of an angiotensin-converting-enzyme gene polymorphism and the risk of ischemic heart disease. $\mathrm{N}$ Engl J Med 1995;332(11):706-711.

31. Sameer AS, Shah ZA, Syeed N, Rasool R, Afroze D, Siddiqi MA. NAD(P)H:quinone oxidoreductase 1 (NQO1) Pro187Ser polymorphism and colorectal cancer predisposition in the ethnic Kashmiri population. Asian Pac J Cancer Prev 2010;11(1):209-213.

32. Sameer AS, Shah ZA, Syeed N, Banday MZ, Bashir SM, Bhat BA, Siddiqi MA. TP53 Pro47Ser and Arg72Pro polymorphisms and colorectal cancer predisposition in an ethnic Kashmiri population. Genet Mol Res 2010;9(2):651-660.

33. Carretero OA, Oparil S. Essential hypertension. Part I: definition and etiology. Circulation 2000;101(3):329335.

34. Luft FC. Molecular genetics of human hypertension. J Hypertens 1998;16(12 Pt 2):1871-1878.

35. Harrap SB. Hypertension: genes versus environment. Lancet 1994;344(8916):169-171.

36. Sipahi T, Budak M, Şen S, Ay A, Şener S. Association between ACE gene Insertion I/ deletion D polymorphism and primary hypertension in Turkish patients of Trakya region. Biotechnol \& Biotechnol. 2006; 20:104108

37. Hsieh MC, Lin SR, Hsieh TJ, Hsu CH, Chen HC, Shin SJ, Tsai JH. Increased frequency of angiotensin-converting enzyme DD genotype in patients with type 2 diabetes in Taiwan. Nephrol Dial Transplant 2000;15(7):10081013.

38. Mondry A, Loh M, Liu P, Zhu AL, Nagel M. Polymorphisms of the insertion / deletion ACE and M235T AGT genes and hypertension: surprising new findings and meta-analysis of data. BMC Nephrol 2005;6(1):1.

39. Pamies Andreu E, Palmero Palmero C, Garcia Lozano R, Stiefel Garcia-Junco P, Miranda Guisado ML, Martin Sanz V, Villar Ortiz J, et al. [The effect of the angiotensinogen M235T and the angiotensin-converting enzyme I/D polymorphisms on arterial hypertension and other cardiovascular risk factors]. Med Clin (Barc) 1999;113(5):164-168.

40. Dzida G, Sobstyl J, Puzniak A, Golon P, Mosiewicz J, Hanzlik J. Polymorphisms of angiotensin-converting en- 
zyme and angiotensin II receptor type 1 genes in essential hypertension in a Polish population. Med Sci Monit 2001;7(6):1236-1241.

41. Duru K, Farrow S, Wang JM, Lockette W, Kurtz T. Frequency of a deletion polymorphism in the gene for angiotensin converting enzyme is increased in African-Americans with hypertension. Am J Hypertens 1994;7(8):759-762.

42. Chiang FT, Chern TH, Lai ZP, Tseng CD, Hsu KL, Lo HM, Tseng YZ. Age- and gender-dependent association of the angiotensin-converting enzyme gene with essential hypertension in a Chinese population. J Hum Hypertens 1996;10(12):823-826.

43. Morise T, Takeuchi Y, Takeda R. Angiotensin-converting enzyme polymorphism and essential hypertension. Lancet 1994;343(8889):125.

44. Nakano Y, Oshima T, Hiraga H, Matsuura H, Kajiyama G, Kambe M. DD genotype of the angiotensin I-converting enzyme gene is a risk factor for early onset of essential hypertension in Japanese patients. J Lab Clin Med 1998;131(6):502-506.

45. Ismail M, Akhtar N, Nasir M, Firasat S, Ayub Q, Khaliq $\mathrm{S}$. Association between the angiotensin-converting enzyme gene insertion/deletion polymorphism and essential hypertension in young Pakistani patients. J Biochem Mol Biol 2004;37(5):552-555.
46. Guyton AC, Hall JE, Lohmeier TE, Jackson TE, Kastner PR. Blood pressure regulation: basic concepts. Fed Proc 1981;40(8):2252-2256.

47. Morshed M, Khan H, Akhteruzzaman S. Association between angiotensin I-converting enzyme gene polymorphism and hypertension in selected individuals of the Bangladeshi population. J Biochem Mol Biol 2002;35(3):251-254.

48. Randhawa NK, Kumar A, Matharoo K, Bhanwer AJS. Association Study of Angiotensin-Converting Enzyme Ins/Del Polymorphism with Hypertension in Punjabi Population. Int J Hum Genet. 2006; 6: 317-321.

49. Bhavani BA, Padma T. Sastry BKS, Krishna Reddy N, Nausheen K. The Insertion I/ Deletion D polymorphism of Angiotensin- Converting Enzyme (ACE) Gene Increase the Susceptibility to Hypertension and / or Diabetes. Int J Hum Genet. 2005; 5: 247-252.

50. Doherty TM, Fitzpatrick LA, Inoue D, Qiao JH, Fishbein MC, Detrano RC, Shah PK, et al. Molecular, endocrine, and genetic mechanisms of arterial calcification. Endocr Rev 2004;25(4):629-672.

51. Samani NJ, Thompson JR, O’Toole L, Channer K, Woods KL. A meta-analysis of the association of the deletion allele of the angiotensin-converting enzyme gene with myocardial infarction. Circulation 1996;94(4):708712 . 